\title{
What is sex journalism or, rather, how does it become? Interviews with news workers on the risk and precarity of a gendered news niche
}

\begin{abstract}
Numerous studies have found the reporting of sex is sensationalized and intended to create controversy while journalists have little regard for the topic. Such matters are important given the \#MeToo movement has broadened public debate about sexual issues, practices and behaviours. However, there is scant research on the professional identities of journalists who specialize in sex news and the industrial, social and individual-level factors shaping their reportage. Extending an earlier qualitative study comprising interviews with female freelance journalists in North America, Canada, Germany and Australia, this article conceptualises sex journalism as a specialism in flux and, using the concept of 'biodigital vulnerability', argues that sex journalists are exposed to gendered experiences of risk in their news work. The results suggest greater consideration for the professional and gendered identities of sex journalists may improve sex news coverage and optimize sexual health outcomes given the importance of sex news as a public information source.
\end{abstract}

Keywords: Journalism studies, journalism theory, sex journalism, sex news, practitioner interviews, professional views

\section{Introduction}

Numerous studies have pointed to poor news coverage of sex that is evident in sensationalised and titillating reporting styles (McBride, Sanders, Janssen, Grabe, Bass, Sparks, Brown and Heiman, 2007), the use of dramatic news language (Wilcox, 2003) and in the dissemination of inconsistent, outdated or incorrect sex information and advice (Boynton 2004; Boynton and Callaghan, 2006). This is lamentable given the topic of sex has 'substantial personal, public and political relevance' and 'accurate and well-articulated' news coverage will arguably improve sexual health outcomes (McBride et.al., 2007: 348). Consequently, calls for a reframing of sex discourse (Hatley Major and Walker, 2010) have coincided with recommendations for greater news worker training and improvement (McBride et.al., 2007). However, a tendency to focus on the shortcomings of sex news has, with notable exceptions, sidelined the perspectives of journalists who write about sex. This is surprising given that a number of predominately female, freelance news workers are embracing the terms 'sex journalist', 'sex positive journalist' and 'sex reporter' in a range of mainstream news articles, digital only publications, radio programs, podcasts and blog posts. On her website 'The Sex Reporter', former Wall Street journalist Loretta Chao describes herself as a 'journalist and multimedia creator specializing in human sexuality', committed to reporting 'the biggest story that isn't (yet) covered objectively and thoroughly - at least not commensurate with its role in our everyday lives' (Chao, 2017). Additionally, there are employment listings for the role of 'Sex and Relationships Reporter' (Mashable, September 2019 and Business Insider, October 2019, see Figures 1 and 2), in what a decade earlier was dubbed a 'new type of media specialty: sex journalism' (Rabble, 2009).

In the first study of sex journalism dedicated to exploring practitioner perspectives, I located the practice of this form of news work among female freelance journalists, many of whom were based in North America, writing for mainstream and alternate media and posting on 
their own blog sites (Middleweek 2019). Their goal was to empower women's voices, accurately disseminate sex information and open up dialogue about 'taboo' topics. Objectives such as these may be considered in the wider context of \#MeToo activism that raised questions about the nuances of sexual interaction and extended public debate about sexual issues, practices and behaviours (Gill and Orgad, 2018: 1314). That broader public discussion about interpersonal matters \#MeToo prompted did not confer on sex journalism a mantle of credibility: rather, journalism about sex remains a lowly and discredited form of news work, largely, as I will argue here, for its historical association with 'feminine' news narratives and issues (Middleweek 2019). While relegating issues so often associated with women is nothing new in journalism (see North 2014), digital-age practitioner perspectives on the practice of this gendered form of news work are worthy of investigation.

Based on 15 in-depth interviews with news workers from the US (9), UK (2), Canada (1), Germany (1) and Australia (2), this article expands on my earlier study of practitioner perspectives of sex journalism (Middleweek 2019) and, using the concept of 'biodigital vulnerability', investigates the experiences of risk underpinning this news work. The research questions guiding this study are what is sex journalism? And what are the experiences of journalists who report on sex and sex-related issues? Structurally, the article will first introduce the scant literature on 'sex journalism' and, in consideration of the gendered dimension of this news work, provide an overview of the symbolic association of women with soft news and declining news standards. What follows is an outline of the qualitative method employed and an ethics statement about the research conducted. Finally, an analysis of the interview findings will inform conclusions reached about the relevance of practitioner perspectives in sex journalism debates.

\section{Sex and journalism}

Despite the visibility of sex in western media (Attwood, 2018), sex news has received 'little attention' (Joseph and Keeble 2019: 3) and is customarily regarded as 'lightweight' and 'the least important feature' in media reports (Boynton and Callaghan, 2006: 341; see also Barker, Gill and Harvey, 2018). In the limited scholarly research on the topic, sex journalism is defined according to different parameters. Mark McLelland locates sex journalism (or sei jānarizumu) historically in the 'upsurge in sexual discourse' in the Japanese kasutori (the 'dregs') or 'sex press' of the 1940s and 50s (2012: 6). He traces its development in increased discussion about sex and erotic material in popular newspapers, magazines and even journals targeting a middle-brow readership (2012: 61, 78). Others such as McBride et.al. (2007) define what they call 'sexual science news' by topic coverage comprising 'sexuality, sexual behavior and sexual health' (2007: 348). For the contributors to Sue Joseph and Richard Lance Keeble's edited collection Sex and Journalism: Critical Global Perspectives (2019) - the first scholarly book on the subject - sex journalism is not limited to a list of topics or traced in shifting Japanese literary tastes. Rather, the chapters examine news representations of 'lovemaking' and 'negative manifestations' of sexual behavior such as sex crimes, sex scandals and sex trafficking. That broader scope gives credence to the argument advanced here that sex journalism is better understood in the context of \#MeToo activism in which issues of consent and the nuances of sexual interaction are at the forefront of public discourse. 
Though competing definitions of sex journalism exist, the majority (with the exception of Joseph and Keeble's collection) tend to take a dim view of this representational practice. In their valuable study of source-journalist interactions in sexual science news, McBride et.al. (2007) found among sex researchers a commonly held view that news media coverage of sex was intended to 'sensationalize, titillate, or create controversy' (McBride et.al., 2007: 351). Elsewhere, the reasons cited were that 'journalists generally do not value sex as a topic', they receive 'scarce formal training', and their reporting evidences 'a lack of evidence-based content and critical questioning' (Boynton and Callaghan, 2006: 334; see also McBride et.al., 2007). These views are based on common perceptions that sex is a 'lite topic that requires little depth or expertise' and 'anyone can offer advice, based on their own experience' (see Barker et. al., 2018). Similarly, in their practical discussion paper for journalists and sexologists Boynton and Callaghan (2006: 334) found that 'Journalists generally do not value sex as a topic, whilst those working within the field of sex do not hold the media in high regard'. The authors also uncovered feelings of frustration among 'sexperts' such as sex educators, sexual health clinicians and therapists in response to what they saw as narrow news coverage of sex and the difficulty of persuading journalists of alternate viewpoints (Boynton and Callaghan 2006: 336-8). These studies offer valuable insight into perceptions of sex news, the professional status of journalists who write about sex and journalist-sex researcher interactions that are often described in oppositional terms and/or as mutually suspicious (McBride et.al., 2007: 354; Boynton and Callaghan, 2006). However, the impact of mainly female freelance journalists reporting on sex has neither been examined nor contextualised in historical debates about soft/hard news binaries that have a gendered dimension.

\section{Gender, journalism and risk}

What counts as newsworthy, the use of particular angles and styles, and professional norms and values regarding 'quality' news indicators such as 'hard' and 'soft' news have long been regarded as expressions of journalism's masculine character (van Zoonen 1989, 1994, 1998; van Zoonen and Donsbach 1988). Historically, whereas hard news such as public affairs, politics, and war have been associated with men (Steiner in Allan 2005: 42), soft news or emotionally laden 'therapy news' (Mayes, 2000: 35) has been coded feminine and associated with 'human interest, consumer news, culture and social policy' (Van Zoonen, 1998: 36; see also North, 2014; Chambers, Steiner and Fleming 2004). In her highly quoted study of Dutch and Norwegian journalists, Liesbet Van Zoonen (1998) found that male journalists' capacity to select topics on the news agenda is one of four principle areas along with story angles, use of sources and ethics that constitute 'the gendered nature of journalism' (36). One consequence of news selection processes that use gender-based quality indicators is that 'what is of interest to women is less important than that which interests men...' (see Allan, 1998 in Ross and Carter, 2011: 1149). Continuing lament about the popular appeal of soft news and personalized styles of reporting (Craig 1994) that have impoverished news quality and caused the 'dumb[ing] down' of society (Nguyen, 2012), further entrench gendered perspectives about news. For several decades, media scholars have challenged these presumptions by arguing that soft news accords with women's lives, has led to the 'opening up of public discourse' (Bird, 2000: 219, see also Turner, 2004; Lumby, 1999), and improved access to abstract and/or complex issues (Baum, 2007; Bird, 2000; MacDonald, 1998). Others have argued that more human interest stories and angles 
have led to the 'feminization of journalism' that may facilitate more professional pathways for aspiring female journalists in a traditionally male ordered field (Van Zoonen, 1998; see also Wahl-Jorgensen and Hanitzsch, 2020).

While conditions of practice have improved since the 1980s and 1990s when much of the feminist critique of journalism first appeared, some continue to attribute declining news quality to the popularity of soft news (Nguyen, 2012). Moreover, the hierarchical ordering of news genres along gendered lines persists (North, 2014) despite the internet's potential to democratize minoritized and marginalised voices. Given the increased production of soft news catalyzed by the internet, commercialization, and intensified competition in news media markets, these debates are arguably more relevant today than ever before (Patterson 2000 cited in Glogger and Otto 2019). In her assessment of women's positioning in contemporary newsrooms, Linda Steiner (2017) argues that women remain in 'low-status media outlets and beats', tend to 'produce "soft news," human interest stories and features' and are 'far from enjoying equity in the online context'. These rusted-on perspectives about the low status of human interest news produced by and for women remain relevant today and are complicated by technologically-driven structural changes in journalism that have popularized freelance, part-time and unpaid work and led to greater conditions of precarity for women (Steiner, 2017). In fact, Steiner goes so far as to argue that 'freelance journalism is women's work' beset by a range of employment risks such as 'unpredictability, uncertainty, low income, limited benefits, and general lack of security'. Though online spaces continue to hold potential for professional and amateur journalists to express contemporary concerns and challenge traditional representations (Steiner, 2017), digital environments function as spaces of both precarity and resistance for the women who contribute to them (Fotopoulou 2017: 16). In her analysis of the terminological link between activism, digital media and embodiment, Aristea Fotopoulou (2017) uses the concept of 'biodigital vulnerability' to capture the complexity of being female and public online, paradoxically both empowered and vulnerable. Empowerment is a consequence of users' greater accessibility to the tools of media production that are politically enabling, while vulnerability Fotopoulou attributes to the experiences of teenage girls, women, transsexual and queer youth who have 'increased expectations for visibility' and are often the targets of cyberbullying, online misogyny and abuse (19). Given the varying degrees of exposure in online spaces that the practice of post-industrial digital journalism requires, biodigital vulnerability offers a ready concept to explore the tensions and capacities that arise in such environments, especially for women.

\section{Method}

This article draws on individual semi-structured interviews conducted by telephone and Skype with journalists based in the US (9), UK (2), Canada (1), Germany (1) and Australia (2) expanding an earlier study of practitioner perspectives of sex journalism (Middleweek 2019). Interview was selected as the most suitable research method given its 'appropriate[ness] for understanding the experiences and meanings associated with gender, race, and class' (see Rakow, 2011: 417). While there is debate about the capacity of interviews to capture women's lived experience (see Kirsch, 2005), as Alasuutari, Bickman and Brannen (2008) argue, feminists have 'highlighted the importance of the interview not only as a place to collect data, but also a site where data is co-constructed, where identities 
are forged through the telling of stories, and where meaning-making begins' (335). The importance of individual storytelling is also affirmed in arguments that scholarly research on sexual discourse should focus on 'the everyday, practical activities through which sexual meanings are produced and reproduced' (Gamson, 1998: 20). Interviewing sex journalists is an attempt to mine those stories and pull focus on the 'everyday, practical activities' of news workers in consideration of journalistic role perceptions and attitudes.

Initially, a Google news search of 'sex and journalism' was undertaken to compile a list of journalists writing about sex, but the majority were interviewed based on the recommendations of existing study participants in a form of snowball sampling. Seidman (2012) argues that recruitment of participants in qualitative research need not be prescriptive and instead proposes two criteria for selection: sufficiency and saturation. In the first instance, sufficiency requires that qualitative researchers obtain enough volunteers to reflect 'the range of participants and sites that make up the population' to ensure those unsampled populations connect with the experiences described by participants (Seidman, 2012: 57). In the second instance, saturation of information is satisfied when the researcher begins to 'hear the same information reported' (57) which is a signal that sufficient interviews have been conducted. These criteria guided the interview process and legitimated the sample size of 15 interviewees. While only modest in size and not an exhaustive sample, the interviewees represent 'a small but strategically important group' (Kunelius and Ruusunoksa, 2008) and their number is in line with other academic studies of practitioner perspectives (see Deuze, 2005b).

The news workers interviewed for this study were all female freelancers reporting across platforms (i.e., online, print, magazines, radio and television) and for digital and traditional media outlets. Some maintained personal blogs, advice or opinion columns about sex while contributing content to digital-only and mainstream news publications in North America, the UK, Germany and Australia. Their versatility across platforms, genres, publications and styles problematizes attempts to classify sex journalism by these criteria and is indicative of the state of 'continuous change' in the field of journalism (Deuze and Witschge 2020: 23). Though the study received university ethics approval one of the stipulated conditions was the removal of identifying features such as the name, pseudonym (if any) and age of interviewees, their city of residence and the publications for which they regularly reported. This was a necessary precaution given the public profiles of some interviewees, lingering taboos about the topic of sex, and the online abuse and harassment many had suffered in the course of their journalistic work. Though the aim of this study has been to address the lack of practitioner perspectives in debates about the quality of sex reportage, future research may take a triangulated approach by combining analysis of news workers views with sex news representations and empirical audience research.

\section{A 'pink ghetto' and female freelancers}

All of the study participants described sex journalism as a female news niche, 'women's realm', 'pigeonhole' or 'pink ghetto' that was unmistakably gendered. Many described the 'stigma and shame' of reporting sex (Interviewees 9 and 10), 'not [being] taken as seriously' (Interviewees 1, 6 and 10), 'not [being] paid as much respect' (Interviewee 11) in their profession, and the prevailing assumption that sex journalism is 'the lowest hanging 
fruit...and devalued as a result' (Interviewee 6). Their description of sex journalism's lowly status accords with previous findings about sex news as 'lightweight' and 'the least important feature' in media reports (Boynton and Callaghan, 2006: 341; see also Barker, Gill and Harvey, 2018). Reasons cited for the predominance of women included the scarcity of male sex writers and educators (eg. 'When I think about sex journalism, I don't think of any men', Interviewee 6), the stigma for men writing on this topic (Interviewee 11), the experiential knowledge required in that 'There are some things you have to have the equipment to understand' (Interviewee 8) and the distrust of 'sex writing from dudes' (Interviewee 10) that was a 'pet peeve' because their writing was usually 'masturbatory or leering' (Interviewee 7). These results echo findings that sex reportage is mainly produced by female freelancers (Boynton and Callaghan, 2006: 341).

Though journalism's casualised labour force cuts across gendered lines and may involve conditions of precarity and risk (Sherwood and O'Donnell, 2018; Gollmitzer, 2014; Deuze, 2007), women tend to comprise the majority of freelance news workers which presents its own set of professional challenges (Steiner, 2017). In fact, Steiner goes so far as to argue that 'freelance journalism is women's work' beset by a range of employment risks such as 'unpredictability, uncertainty, low income, limited benefits, and general lack of security'. These risks were among those interviewees described as the impacts of the 'enormous gig economy' in which contemporary journalism is now practised and can be felt economically (eg. 'you have to become a generalist sex journalist to survive' Interviewee 4), psychologically (eg. feeling 'extremely scared', 'vulnerable' and 'violated' as a result of pressure from 'coercive' editors 'to do things I didn't want to do' in pursuit of a story, Interviewee 12) and physically, in stalking and violent behaviours from readers (Interviewees 12,14). I will shortly probe these threats further in the context of the boundary work sex journalists exercise to manage particularly gendered forms of risk; suffice to say here that the insecurity of impermanent employment arrangements which often resulted in economic hardship, shifted notions of responsibility and enterprise through self-employment, rising levels of stress and a lack of organizational protection and support were common experiences among the sex journalists interviewed for this study and can be felt in the wider context of post-industrial journalism practice (see Deuze and Witschge, 2018). In response to those professional risks sex journalists have cultivated 'female camaraderie' and 'peer support' because 'there is a sense of community peculiar to writing about sex' (Interviewees 1, 5, 12 and 14). Arguably, these community-building initiatives are important for strengthening ties in what Deuze and Witschge (2018: 176) call 'networks of loosely-affiliated competitor-colleagues' that stretch across and beyond institutional boundaries and are a feature of the current decentralized news landscape.

\section{Sex journalism origins and \#MeToo}

Most of the interviewees traced the origins of sex journalism, as a distinct genre, to the 1980 s with the launch of publications such as On Our Backs, the first sex positive periodical produced by women (Interviewee 15). For others, it was 'more sexual permissiveness in general' in the 1990s and 'the representation of women's sexual narratives' in media such as the HBO television series Sex and the City (Interviewee 1). Some recollected online publications such as Nerve.com (described as a precursor to Vice) that contained the earliest forms of sex reportage (Interviewee 3 ) and/or identified journalists they attributed with 
founding the genre such as Susie Bright, Violet Blue and Rachel Rabbit White 'the first person who called herself a sex journalist' in 2009 (Interviewee 3). Interviewees also considered macro-structural factors when tracing the roots of sex journalism. Developments in digital technology were seen as crucial because 'The internet finally gave a place to put this content' (Interviewee 2), 'democratised the ability to write about sex' (Interviewee 4) and provided 'a lot of space online for women to speak their truth' (Interviewees 10, 7). However, as I will illustrate in subsequent analysis of the interview data, digital technologies also expose sex journalists to targeted forms of harassment and abuse and reveal the paradoxical conditions of empowerment and vulnerability characterizing their online storytelling experiences (Fotopoulou, 2017, see also Middleweek 2020). The \#MeToo movement was seen as a catalyst for sex reportage because it 'opened up a conversation and awareness about sex' (Interviewee 9), '...raised a lot of questions about the nuances of sexual interaction to a degree we haven't seen before' (Interviewees 6 and 11), and occasioned the 'wholesale redefining of gender, desire, sexual orientation and behaviours' (Interviewee 4). Interviewee reflections on the importance of \#MeToo for raising public awareness and spotlighting attention on the nuances of sexual interaction and behavior corresponds with research on \#MeToo's broader impacts (Gill and Orgad, 2018: 1314).

Concerning style, there was no consensus on the literary influences informing sex journalism. Some referred to the literary movements of the 1960s such as 'new journalism' as well as 'creative non-fiction' (Interviewees 1 and 3) and 'narrative non-fiction journalism' (Interviewee 4). These genres had in common with sex journalism the frequent use of firstperson point-of-view 'where the writer involves themselves in some way' in the story (Interviewee 3) by acting as the 'journalist emissary into another world' (Interviewee 6) whether that was 'trying out a crazy new sex toy' or 'going to an erotic dinner party' (Interviewee 6). Overwhelmingly, all of the sex journalists interviewed wanted to be taken seriously for their writing and aspired to produce quality sex journalism - what one cheekily inferred when she implored 'When does the first sex journalist win a Pulitzer?' (Interviewee 4). These responses are in stark contrast to findings in sex journalism research that journalists hold little regard for sex as a news topic (Boynton and Callaghan, 2006). In fact, the interviewees in this study were highly reflexive about their news work and took seriously their responsibility to educate both 'the intellectual end of the spectrum' and a wider audience through 'more accessible' content (Interviewee 12).

The question 'What is sex journalism?' yielded an array of answers that could be summarized in one interviewee's remark 'Sex journalism can be so many different things' (Interviewee 11). Their lack of agreement is not surprising given the few and contested definitions of sex news in scholarly research (see Middleweek 2019: 4 and cf. McBride et.al., 2007 with McLellan, 2012). Some interviewees attributed to sex journalism a list of topics commonly reported such as 'sex, health, dating, business trends' (Interviewee 4) or 'sex, relationships, psychology, fashion, beauty, sexual orientation, mental health and improvement' (Interviewee 3). Others pointed to a 'collective interest in the topic of sexuality' (Interviewee 1) or suggested that 'It's about health and relationships' (Interviewee 8). 'Quality' indicators also provided a yardstick for interviewees comparing different types of sex journalism from 'science work' to the more tabloid 'Cosmo fluff' (in reference to the popular women's glossy magazine Cosmopolitan) as typified in the advice stories '10 ways to make him harder' or '[How] to be a temptress in bed' (Interviewee 2). That view was 
echoed in interviewees' remarks about the limited publication alternatives for sex journalists who could either 'sell shit to Cosmo or serious to Slate' (Interviewee 4). Some interviewees thought publishers should be responsible for any tabloidese or sensationalist reportage since they 'want to box [sex] up, don't want to offend... they want to titillate not educate' while another described being '...restricted in the way that I'm edited' (Interviewee 12). These findings complicate existing arguments that attribute poor news coverage of sex to the intention of news workers to sensationalise (Boynton and Callaghan, 2006), given that they overlook the wider, structural issues impacting news production. As the following section will tease out, the main point of consensus among sex journalists was their insistence on ideal-typical values and particular skills that news workers require in their reportage of sex.

\section{Ideal-typical values, a specialist skill set and defining sex journalism}

The specialist skillset required of sex journalists was described by interviewees as a 'sense of empathy' (Interviewees 1, 5, 10 and 14) given 'there's still a lot of shame around sex' (Interviewee 5) and 'you have to feel less shame' (Interviewee 10). Empathy is understood to be 'perceiving the emotions of others' and, in a news context, related to 'the deployment of emotions in news and in engaging audiences' (Glück, 2016: 894). Some of the reasons cited for this empathetic approach are that sources are 'vulnerable' (Interviewee 1), 'you encounter things that are gross and weird or upsetting' (Interviewee 3) and 'people are going to tell you the craziest things' (Interviewee 4). Interviewees also described their empathetic approach as a 'bodies and relationships skillset' (Interviewee 9) that is 'less heterosexually focused' (Interviewee 5), 'requires a maturity' (Interviewee 7) and is evident in the use of preferred gender pronouns and an understanding of journalism's social privilege (Interviewees 1 and 4). Several pointed to the need for an 'open mind' that 'put[s] aside the cultural mores' (Interviewees 2, 4, 7 and 14), a 'sensitive' approach (Interviewee 3) and 'a level of non-judgmentalness' (Interviewee 11). The sex journalist traits interviewees related are variations of an empathetic skillset lately recognized as a 'core skill' of news workers operating in 'sensitive journalistic work fields' (Glück, 2016). Arguably, sex journalism is the prototypical 'sensitive journalistic work field' given the subject matter may involve discussion of non-normative sexual behaviours, practices and identities, interviewing marginalized and/or vulnerable groups and the reporting of experiences of sexual harassment and abuse that rely on high degrees of trust and empathy in journalistsource interactions.

Though interviewees acknowledged western journalism's professional ideology of 'objectivity, detachment, and neutrality' (see Hanitzsch and Vos 2017: 127) as indicated in one interviewee's response 'journalism is journalism' (Interviewee 4), their insistence on the need for an empathetic skillset points to the wider social trend of emotionalization in journalism (McQuail, 2010: 357). Arguably, the exercise of traits such as 'subjectivity, empathy and emotions' are characteristic of a 'feminine journalism' (Djerf-Pierre 2007: 91), and would suggest that sex journalists are at the forefront of this social phenomenon. Embracing these so-called 'soft' skills politicizes topics too often regarded as trivial or frivolous because of their association with or particular relevance to women (Ruoho and Torkkola, 2018; see also Van Zoonen, 1998). Given the diversity of perspectives on what constitutes the object sex journalism (i.e., disagreement about the topics sex journalism 
encompasses and the style of writing it resembles), a more useful definition would recognize those common 'soft', empathic skills among practitioners. Indeed, such an approach follows in the tradition of defining journalism according to professional standards of newsmaking (see Deuze, 2005a; Deuze and Witschge, 2018) that are cultivated by journalists who write about sex. As I argued in the original study that this research extends, sex journalism can be defined as 'a collective interest in the topic of sex and sexuality that is reported in a factual and timely manner with regard for the social and ethical considerations of journalism practice and ideal-typical values of open-mindedness, empathy and boundarysetting' (Middleweek 2019). In this definition I had hoped to reconcile the tensions among various ways of seeing sex journalism and bound the object of study.

However, as the additional interviews made clear defining what sex journalism is - even by a sliver of consensus on the required skillset - implies a consistent body of knowledge or, at the very least, concreteness and fixity in meaning. Yet, the empirical findings both here and in the original study reveal myriad practices, divergent understandings and competing occupational ideologies governing sex journalism practice. So, while this study primarily asks, 'What is sex journalism?' it would be more appropriate to interrogate, 'How does sex journalism become?' By asking what sex journalism becomes we acknowledge diversity in the lived experience of professional journalists whose conditions of practice are typically fragmented, precarious and networked (Deuze and Witschge 2020). Indeed, as the findings here reveal, that experience of precarity is all the more apparent for female freelancers who report on the subject of sex. For Mark Deuze and Tamara Witschge (2020), we must move beyond a conceptualization of contemporary journalism as 'a distinct and boundaried organization of newswork' in favour of its reimagining as process, as 'moving object' and, therefore, 'continuously becoming' $(2020: 7,23)$. To do so acknowledges journalism's shapeshifting character: not fixed in time, space or meaning but dynamic and changeable. Taking a processual approach to the study of sex journalism involves mapping the 'divergent practices, definitions as well as ideological interpretations' surrounding sex journalism and among sex journalists. It is being attentive to the experiences of individual journalists, their differing milieu and the dynamic configuration of relations of which they are a part (Deuze and Witschge 2020). In the following section different ways of doing and seeing sex journalism - that is, empowering as well as oppressive - are considered in the context of the risk and precarity underlying news work about sex.

\section{Boundary work and gendered experiences of risk and precarity}

Consistent with the paradoxical experience of women's 'biodigital vulnerability' (Fotopoulou, 2017) in online spaces, some interviewees described sex journalism as an 'empowering experience at first' (Interviewee 5) and that news practitioners 'are entrepreneurs - not all victims - [some of whom] have built dynasties in the porn world' (Interviewee 2). ${ }^{1}$ However, the majority of interviewees described the professional risks that beset journalists who cover the sex beat. They include 'moral ramifications' arising from this type of news work (Interviewee 1) and the fact that 'people get different ideas about who you are as a journalist. You get pigeonholed' (Interviewee 2). Interviewees described being

\footnotetext{
${ }^{1}$ While some quotations might suggest a link between sex journalism and pornography, none of the journalists interviewed for this study claimed to have worked in the adult entertainment industry. Instead, some mentioned the news stories they had written about the industry.
} 
'heavily defined' for writing about sex and the surprise of editors who '...did not expect you to be an intellectual, literate or well spoken, a writer. It was as if I was just going to be drooling sitting there with my vibrator' (Interviewee 15). Unlike other news genres, sex journalism is 'more precarious to one's professional identity' (Interviewee 2) and in college many interviewees were discouraged from the pursuit or advised to use a pseudonym because 'sex journalism is not going to pay your bills' (Interviewees 2 and 11). In response to those professional risks, interviewees stated that 'You have to constantly make your own boundaries known' (Interviewee 5), for example, in negotiations with editors about story treatment and coverage, in managing readers who violate your privacy, in accepting the professional and personal consequences of visibility through an online public profile and in addressing prevailing stereotypes such as, 'I'm certainly not the polyamorous extreme fetishist that people think I am' (Interviewee 12) and 'People imagine I'm a crazy nympho with a fountain pen' (Interviewee 15). Boundary work, therefore, emerged as an idealtypical value among sex journalists. This finding parallels research on the professional norms and values of journalists of all stripes for whom the use of 'boundary markers' serves to differentiate professionals from amateur journalists in online environments (Singer in Carlson and Lewis, 2015). In the context of this study, boundary work functioned as an important marker of occupational identity with interviewees preferring to use the terms 'sex journalist', 'sex writer' and 'journalist who writes about sex' rather than 'sexpert' as evident in comments such as 'I'm not a 24-hour free sex advice service' (Interviewee 12) and in the insistence that theirs is a job with obligations around research, fact-checking and accurate reportage.

Overwhelmingly, boundary work was a strategy for managing personal safety and, in the absence of any comment about the mechanisms publishers put in place to protect sex journalists from gender-based harassment and abuse, was inferred to be an individual-level responsibility. They described the 'war correspondent mentality' (Interviewees 1 and 4) and 'psychological warzone' (Interviewee 1) that comes with this form of news work in which 'your mental state and your body [is] on the line in the pursuit of a story' (Interviewee 4). Examples included 'obnoxious comments', 'threatening and gendered slurs' (Interviewee 11 ) and '...a lot of online hate and harassment which I didn't know how to cope with' (Interviewee 1). Interviewees appeared to dismiss the more 'common' experiences of abuse such as receiving 'unsolicited dick pics' and invitations from readers 'looking for slaves' in sado-masochistic relationships (Interviewee 12). But there were more frightening examples of journalists suffering post-traumatic stress disorder (Interviewee 1), feeling 'physically unsafe' (Interviewee 3 ) and being 'targeted by men' who 'encouraged me to take my own life' (Interviewee 12). Others described 'trolls publicizing embarrassing things about me' online such as personal contacts, family relationships and even graphic details about their genitalia (Interviewee 12). There were also horrifying examples of 'panic buttons', restraining orders and death threats in anecdotes such as, "he felt my words - because they were so personal - were speaking actually to him, the reader, and when I didn't respond to all this mail he felt rebuffed and took it personally and wanted to kill me' (Interviewee 14). Their 'increased expectations for visibility' as women may be one reason sex journalists are targets of cyberbullying, online misogyny and abuse (Fotopoulou, 2017: 19). Another reason cited by several interviewees was a prevailing misogyny in western society in which 'people hate women' and men tend to ask 'Are you that slut who wrote about... whatever' (Interviewee 10,14). Interviewees agreed that reporting sex often leads audiences to 
suppose the sexual promiscuity of the journalist (eg. 'there are people who assume l'll be hyper-sexual', Interviewee 12) as evident in the highly gendered, sexist language readers use to address sex journalists as a 'slut', 'bitch', 'whore', 'tart' and 'slag' (Interviewees 12 and 14). These views tap into the historical 'sexual double standard' (SDS) around men's and women's sexual conduct that involves a more negative assessment of women who exhibit the same sexual behavior or attitudes as men (Gómez Berrocal, Vallejo-Medina, Nieves, Carlos, 2019; Kreager and Staff, 2009).

Regardless of fears for their own safety, interviewees were motivated by a professional obligation to ensure accurate sex reportage in comments such as 'I want people to take the subject of sex seriously... it deserves the same thought, attention and analysis that we give to every area of our lives' (Interviewee 13), 'I'm driven to educate people and empower them' and 'a lot of times it's advocating for women's pleasure' (Interviewee 14) and 'What you say can affect how people think about sex and that's a really big responsibility' (Interviewee 5). Interviewees described a range of responsible reporting practices they exercised in their daily news work. These included earning the trust and ensuring the anonymity of sources where appropriate (Interviewees 5 and 12); relying on authoritative and expert sources to substantiate content (Interviewee 13); exercising self-restraint (eg. 'If [the topic] is something that turns you on then you need to take a step back', Interviewee 2) and transparency about professional expertise (eg. 'I don't have any special certification in the sexual health or mental health field', Interviewees 11, 13 and 14). Some even shared with readers links to online educational resources and contacts for professional sex therapists/counselling services (Interviewee 12) and rejected story commissions if individual value systems were breached (Interviewees 12 and 14). These self-described news worker practices are evidence of sex journalists reflecting on '...their own boundaries, biases, and values related to sex, with the same attempt to be objective as they strive for in their journalistic work' - what is McBride et.al.'s (2007) key recommendation for sex journalist training to improve the standard of reportage.

\section{Conclusion}

Extending an earlier qualitative study of practitioner perspectives (Middleweek 2019), this study has analysed professional news workers' views about sex reportage in the context of \#MeToo's broader public debate about sexual issues, practices and behaviours (Gill and Orgad, 2018: 1314). What emerged from the research, and in support of my earlier findings, was that sex journalism is a gendered news niche, devalued for its association with feminine news narratives and issues. In the earlier study, I offered a definition of sex journalism based on common interviewee reflections about ideal-typical values such as an empathetic skill set, open-mindedness and boundary-setting. The additional interviews conducted here revealed that boundary work was not only a mark of occupational distinction for sex journalists who espoused professional standards of ethics, accountability and transparency, but also a strategy to mitigate the risks encountered in this form of news work. Some of those risks related to the impermanent employment arrangements of post-industrial journalism practice realized in economic hardship, rising stress levels and the additional responsibilities of self-employment for freelancers (Deuze and Witschge, 2018). But, as this study found, freelance sex journalists are exposed to additional risks as a consequence of their gender, considered here via the concept of 'bio-digital vulnerability' (Fotopoulou, 
2017). Those risks ranged from gendered slurs, misogynistic-fueled hate speech and public shaming of women's genitalia to stalking, intimidation, incitements to self-harm, physical violence and death threats. As one interviewee confided, 'It's definitely made my life hard' (Interviewee 12) and another, 'I commiserate with other sex journalists' (Interviewee 14).

Recommendations for improving topic coverage through journalists' greater self-reflexivity about '...boundaries, biases, and values related to sex' (McBride et.al., 2007: 356), is evident in the depth of practitioner perspectives collected in this study. As one interviewee described, 'the boundary piece of the puzzle is so huge' (Interviewee 14) and all were remarkably candid in relating anecdotes of boundary-setting with editors, publishers and audiences. In their advocacy for an empathetic skillset and the exercise of boundary-work in sex journalism, interviewees in this study exemplify professional reflexivity and the wider social trend of emotionalization in journalism (McQuail, 2010: 357). Arguably, sex journalists are at the forefront of this social phenomenon in their practice of 'subjectivity, empathy and emotions' that are characteristic of a 'feminine journalism' (Djerf-Pierre, 2007: 91).

Carving a definition of sex journalism has been an attempt to find mutual agreement, that is, a shared understanding of what sex journalism is in an array of conflicting perspectives both within the limited scholarship on the subject and among sex journalists themselves. But, as apparent in the additional interviewee insights collected here, it is more productive to ask what sex journalism becomes. Hence, any attempt to understand sex journalism must eschew external definitions about its function or purpose and instead acknowledge individual sense-making - what Deuze and Witschge call 'theorizing from the ground-up' in the varying activities and practices that emerge in practitioner reflections on their news practice (2020: 28). In so doing, we might re-think widely accepted views that sex journalism is sensationalist and controversial as well as characterisations of sex reportage as uncritical and unsubstantiated (see Boynton and Callaghan, 2006: 334; see also McBride et.al., 2007). This is because blanket assumptions about 'quality' impose a definition from outside that is predicated on what sex journalism should or could be, ignoring the ongoing transformations that occur. Although there are plentiful examples of titillating news stories about sex, it is far more instructive to consider the complex system in which journalists operate that is informed by historical views about sex as a women's issue and a discredited form of journalism responsible for the 'dumb[ing] down' of society (Nguyen, 2012). Furthermore, steadfast perspectives about sex journalism overlook the industrial and individual-level tensions arising from differing expectations around news work (eg. 'coercive editors', Interviewee 12), the shifted responsibility freelancers shoulder in self-employment ('I have to make a living', Interviewee 12), and persistent social attitudes about women and sex (eg. '...if you've written about sexual politics or sexuality per se there's this sense that you cannot get your head out of your vagina', Interviewee 15). Added to that, widely accepted criticisms of sex reportage ignore the personal and professional toll of news work that often compromises the psychological, economic and physical safety of practitioners. News workers in this study firmly indicated that they strive for quality reportage of sex and take seriously their responsibility to educate both 'the intellectual end of the spectrum' and a wider audience through 'more accessible' content (Interviewee 12). Overall, the findings suggest that greater consideration for the professional and gendered identities of sex journalists may well improve sex news coverage and, by extension, optimize sexual health 
outcomes given sex news is an important source of information for the public (McBride et.al., 2007: 348). 


\section{LIST OF REFERENCES}

Alasuutari P, Bickman L and Brannen J. eds. (2008) The Sage Handbook of Research Methods, London: Sage Publications.

Attwood F (2018) Sex Media, Cambridge: Polity Press.

Bell A (1991) The Language of News Media, Oxford: Blackwell

Bird SE (2000) Audience demands in a murderous market: Tabloidization in US television news, In: Tabloid Tales: Global Debates Over Media Standards, Sparks C and Tulloch J (eds) Oxford: Roman \& Littlefield Publishers, pp 213-228

Boynton PM and Callaghan W (2006) Understanding media coverage of sex: A practical discussion paper for sexologists and journalists, Sexual and Relationship Therapy, 21(3): 333346.

Boynton PM (2004) Beware the sexperts. The Guardian, 30 July.

Chambers D, Steiner L and Fleming C (2004) Women and Journalism, London, New York: Routledge

Chao L (2017) The Sex Reporter. Website. Available at: https://thesexreporter.com/ (accessed 18 December 2019)

Cohen S and Young J (1973) The Manufacture of News: A Reader, London: Sage Publications

Craig G (1994) "Press photographs and news values", Australian Studies in Journalism 3.

Deuze M and Witschge T (2020) Beyond Journalism, Cambridge: Polity Press.

Deuze M and Witschge T (2018) Beyond Journalism: Theorizing the Transformation of Journalism, Journalism, 19(2): 165-181. DOI: 10.1177/1464884916688550

Deuze M (2007) Media Work. Cambridge: Polity Press.

Deuze M (2005a) What is journalism? Professional identity and ideology of journalists reconsidered. Journalism, 6(4): 443-465

Deuze M (2005b) Popular journalism and professional ideology: Tabloid reporters and editors speak out, Media, Culture and Society, 27(6): 861-882

Djerf-Pierre M (2007) The Gender of Journalism The Structure and Logic of the Field in the Twentieth Century, Nordicom Review, Jubilee Issue. 81-104. 
Fotopoulou A (2017) Feminist Activism and Digital Networks: Between Empowerment and Vulnerability. London, UK: Palgrave Macmillan.

Fox $A$ and Kale $S$ (2018) Working as a sex journalist taught me when to say no, Vice, 14 September. Available at:

https://www.vice.com/en us/article/mbwjzn/working-as-sex-journalist-alix-fox (accessed

18 December 2019)

Galtung J and Ruge M (1965) The structure of foreign news: The presentation of the Congo, Cuba and Cyprus Crises in four Norwegian newspapers, Journal of International Peace Research, 2: 64-90.

Gamson J (1998) Freaks Talk Back: Tabloid Talk Shows and Sexual Noncomformity, Chicago: University of Chicago Press.

Gill R and Orgad S (2018) The shifting terrain of sex and power: From the 'sexualization of culture' to \#MeToo, Sexualities, 21(8): 1313-1324

Gill R (2007) Gender and the Media. Cambridge: Polity Press.

Glogger I and Otto LP (2019) Journalistic Views on Hard and Soft News: Cross-Validating a Popular Concept in a Factorial Survey, Journalism \& Mass Communication Quarterly, 96(3): 811-829. doi: 10.1177/1077699018815890.

Glück A (2016) What Makes a Good Journalist? Journalism Studies, 17:7, 893903, DOI: $\underline{10.1080 / 1461670 X .2016 .1175315}$

Gollmitzer M (2014) Precariously employed watchdogs? Perceptions of working conditions among freelancers and interns, Journalism Practice (8(6): 826-41.

Gómez Berrocal M, Vallejo-Medina P, Nieves M, Carlos SJ (2019), Sexual Double Standard: A Psychometric Study From a Macropsychological Perspective Among the Spanish Heterosexual Population, Frontiers in Psychology, 10: 1869 https://doi.org/10.3389/fpsyg.2019.01869

Hanitzsch T and Vos TP (2017) Journalistic Roles and the Struggle Over Institutional Identity: The Discursive Constitution of Journalism, Communication Theory, 27(2): 115135, https://doi.org/10.1111/comt.12112

Harcup T and O'Neill D (2017) What is News? News values revisited (again), Journalism Studies, 18(12): 1470-1488, DOI: 10.1080/1461670X.2016.1150193

Harcup T and O'Neill D (2001). What is News? Galtung and Ruge Revisited. Journalism Studies 2 (2): 261-280.

Hatley Major L and Walker KK (2010) Newspapers lack substantive reporting on sexual issues, Newspaper Research Journal, 31(4): 62-76. 
Herbert J (2000) Journalism in the Digital Age, Oxford: Focal Press

Hetherington A (1985) News, Newspapers and Television, London: Macmillan

Joseph S and Keeble RL (eds.) (2019) Sex and Journalism: Critical, Global Perspectives, UK: Bite-Sized Books.

Kraeger DA and Staff J (2009) The Sexual Double Standard and Adolescent Peer Acceptance, Social Psychology Quarterly, 72(2): 143-164.

Kunelius R and Ruusunoksa L (2008) Mapping professional imagination, Journalism Studies, 9(5): 662-678

Lumby C (1999) Gotcha: Life in a Tabloid World, Sydney: Allen \& Unwin

MacDonald M (1998) Politicizing the personal: Women's voices in British television documentary. In: Allan S, Branston G and Carter C (eds) News, Gender and Power, New York: Routledge.

MacDougall C (1955 [1948]) Interpretive Reporting. MacMillan Company of Canada, Toronto. Available at:

https://archive.org/stream/in.ernet.dli.2015.275227/2015.275227.Interpretative-

Reporting djvu.txt (accessed 29 November 2019).

Mayes T (2000) Submerging in "Therapy News"' British Journalism Review, 11(4): 30-35.

McBride KR, Sanders SA, Janssen E, Grabe M, Bass J, Sparks JV, Brown TR, and Heiman JR (2007) Turning Sexual Science into News: Sex Research and the Media, Journal of Sex Research, 44(4): 347-358

McLelland M (2012) Love, Sex and Democracy in Japan during the American Occupation, New York: Palgrave MacMillan

McQuail D (2010) McQuail's Mass Communication Theory. 6th ed. Los Angeles \& London: Sage.

Middleweek B (2020) Pussy power not pity porn: Embodied protest in the \#FacesOfProstitution Twitter network, Sexualities: studies in culture and society, vol. 23, no. 3.

Middleweek B (2019) In a pink ghetto: how female news workers define sex journalism. In: Joseph, S \& Keeble, R (eds) Sex and Journalism: Critical Global Perspectives, BiteSized Books, UK, pp. 9-19.

North L (2016) The Gender of "soft" and "hard" news, Journalism Studies, 17:3, 356373, DOI: $10.1080 / 1461670 X .2014 .987551$ 
Parks, Perry (2018) Textbook news values: Stable concepts, changing choices, Journalism \& Mass Communication Quarterly. Available at: https://doi.org/10.1177/1077699018805212 (accessed 18 December 2019)

Rabble (2009) Become a Sex Journalist! job advertisement, Available at: http://www.rabble.ca/babble/babblers-helping-babblers/become-sex-journalist (accessed 18 December 2019)

Rakow LF (2011) Commentary: Interviews and Focus Groups as Critical and Cultural Methods, Journalism \& Mass Communication Quarterly 88: 416-428.

DOI: $10.1177 / 107769901108800211$

Ross K and Carter C (2011) Women and news: A long and winding road, Media, Culture \& Society, 33(8): 1148-1165

Ruoho I and Torkkola S (2018). Journalism and Gender: Toward a Multidimensional Approach, Nordicom Review 39(1): 67-79. doi:10.2478/nor-2018-0002.

Sherwood M and O'Donnell P (2018) Once a Journalist, Always a Journalist? Journalism Studies, 19(7), 1021-1038, DOI: 10.1080/1461670X.2016.1249007

Singer JB (2015) Out of bounds: Professional norms as boundary markers. In: Carlson M and Lewis SC (eds) Boundaries of Journalism: Professionalism, Practices and Participation, London, New York: Routledge pp 21-36

Steiner L (2017), Gender and Journalism, Oxford Research Encyclopedia, Communication. Oxford University Press, USA.

DOI: $10.1093 /$ acrefore/9780190228613.013.91

Steiner L (2005) The 'gender matters' debate in journalism: Lessons from the front, In: Allan $S$ (ed.) Journalism: Critical Issues, Berkshire, England, Open University Press pp. 42-53

Stovall JG (1990) The practitioners. In: Sloan WD (ed.) Makers of the Media Mind: Journalism Educators and their Ideas, New York, London: Routledge pp 23-58

Tumber H (ed.) (1999) Journalism: Critical Concepts in Media and Cultural Studies, London: Routledge

Tunstall J (ed.) (1970) Media Sociology: A Reader, London: Constable

Turner G (2004) Understanding Celebrity, London: Sage Publications

Van Zoonen L (1998) One of the Girls? The Changing Gender of Journalism, In: News, Gender and Power, Carter C, Branston G and Allan S (eds), London: Routledge, pp33-46.

Van Zoonen L (1994) Feminist Media Studies, London: Sage. 
Van Zoonen L (1989) Professional Socialization of Feminist Journalists in The Netherlands, Women's Studies in Communication 12(3): 1-23.

Van Zoonen L and Donsbach W (1988) Professional Values and Gender in British and German Journalism, paper presented to the 38th Annual Conference of the International Communication Association, New Orleans.

Wahl-Jorgensen K and Hanitzsch T (eds) 2020. The Handbook of Journalism Studies. 2nd edtn. New York: Routledge.

Wilcox SA (2003) Cultural context and the conventions of science journalism: Drama and contradiction in media coverage of biological ideas about sexuality. Critical Studies in Media Communication, 20: 225-247.

Women of Sex Tech (2019), Future of Sex writer, job advertisement, Available at:

https://www.womenofsextech.com/future-of-sex-writer (accessed 18 December 2019) 